\title{
Pengembangan Agrowisata Berbasis Masyarakat Di Desa Lamajang Kabupaten Bandung
}

\author{
Titing Kartika ${ }^{1}$, Emron Edison ${ }^{2}$, Rizwan Nugraha ${ }^{3}$ \\ nengtiting_kartika@yahoo.co.id,emron.bdg@gmail.com,rizwannugraha75@gmail.com
}

\begin{abstract}
Lamajang Village, Bandung Regency has 5.5 ha of agricultural land and Animal Husbandry which is managed directly by the community. These farms include fruits, vegetables, medicinal plants, others, having sheep, chicken, fish and pigeon farms. This research was conducted to find out what agrotourism activities could be carried out, to what extent agrotourism had been developed, and to know the role of the community in agrotourism activities. The research method used is a qualitative research method. Data collection techniques were carried out by means of observation, interviews, and documentation studies, primary data sources were obtained from people who work in agriculture and secondary data sources were directly collected by researchers as support from the first source. The results showed that the Oldjang Village agrotourism has a fairly good agricultural potential. However, there is no mapping, understanding of the concept of agrotourism and the absence of facilities that support Agro-tourism Development in Lamajang Village.
\end{abstract}

Keywords: Agrotourism Development, Community Based

Desa Lamajang Kabupaten Bandung memliki Lahan pertanian 5,5 ha dan Perternakan yang dikelola langsung oleh masyarakat. Lahan pertanian ini diantaranya pertanian buah - buahan, sayuran, tanaman obat dan lain - lain, memiliki perternakan domba, ayam, budidaya ikan dan burung merpati. Penelitian ini dilakukan untuk mengetahui apa saja kegiatan agrowisata yang bisa dilakukan, sejauh mana agrowisata yang telah dikembangkan, dan mengetahui peran masyarakat dalam kegiatan agrowisata. Metode penelitian yang digunakan adalah metode penelitian kualitatif. Teknik pengumpulan data dilakukan dengan cara observasi, wawancara, dan studi dokumentasi, sumber data primer diperoleh dari masyarakat yang bekerja di pertanian dan dumber data sekunder yang langsung dikumpulkan oleh peneliti sebagai penunjang dari sumber pertama. Hasil penelitian menunjukan bahwa agrowisata Desa Lamajang memiliki potensi pertanian yang cukup baik Namun demikian belum adanya pemetaan, pemahaman tentang konsep agrowisata dan belum adanya fasilitas yang menunjang Pengembangan Agrowisata di Desa Lamajang. 


\section{PENDAHULUAN}

Beberapa pakar pariwisata telah melihat satu sisi pengembangan dengan memberdayakan lahan pertanian yang berada di pedesaan dan memiliki potensi untuk dijadikan daya tarik wisata alternatif. Berbagai penelitian telah dilakukan, penelitian yang terkait dengan pengembangan pariwisata berbasis sumber daya pertanian atau yang sering disebut agrowisata yaitu yang hasilnya menunjukan bahwa, akhir-akhir ini terdapat pergeseran minat wisatawan terhadap produk wisata yang diinginkan. Wisatawan cenderung menginginkan melakukan berbagai kegiatan wisata dilokasi yang relatif sepi dan alami, memiliki udara yang bersih dan segar serta mempunyai atraksi yang menarik dan unik. Karakteristik tersebut pada umumnya dimiliki oleh kawasan pedesaan.

Menyikapi hal seperti itu diperlukan pilihan bijak yaitu mengembangkan sinergitas pariwisata dengan pertanian dengan membentuk wisata alternativ ramah lingkungan, berkeadilan seperti agrowisata. Agrowista atau wisata pertanian didefinisikan sebagai rangkaian aktivitas perjalanan wisata yang memanfaatkan lokasi atau sektor pertanian mulai dari awal produksi hingga diperoleh produk pertanian dalam berbagai sistem dan skala dengan tujuan memperluas pengetahuan, pemahaman, pengalaman, dan rekreasi di bidang pertanian (Nurisjah, 2001). Adanya pengembangan agrowisata di pedesaan yang berbasis masyarakat setempat diharapkan dapat memberi manfaat yang banyak, tidak saja bagi masyarakat perdesaan tetapi juga masyarakat perkotaan untuk lebih memahami dan memberikan apresiasi pada bidang pertanian serta menjadi sarana edukasi.

Pertanian dan perternakan menjadi hal utama perkembangan Agrowisata ini dilihat dari potensi kedua hal tersebut Agrrowisata akan berjalan dengan baik, Perdesaan yang ada khususnya di Indonesia sendiri pasti memiliki lahan pertanian maupun peternakan seperti di Desa Lamajang Kabupaten Bandung, Pertanian di Desa lamajang ini bisa dibilang sedang berkembang dengan pesat dilihat dari mata pencaharian masyarakat di Desa Lamajang ini sebagian besar bermata pencaharian sebagai petani, baik petani Padi, Buah - buahan, sayuran maupun tanaman obat lainnya. 
Masyarakat di Desa Lamajang ini memiliki Lahan Pertanian yang sangat luas dan di tanami beberapa tanman yang dimana hasil tani dari lahan pertanian ini kebanyakan menjadi konsumsi pribadi masyarakat di Desa Lamajang, ada juga yang dijual kepada pengepul untuk mendapatkan keuntungan dari hasil tani hanya saja tidak banyak akrean kurang nya pola pikir ekonomi petani untuk kedepannya, tetapi dengan begitu para petani di Desa Lamajang sudah merasa cukup untuk perekonomian hidupnya dengan hal demikan.

Desa Lamajang ini memiliki potensi yang ada dipadukan dengan objek wisata dan suguhan pemandangan yang sangat indah potensi yang terdapat di lahan pertanian kampung parabon ini adalah tanaman kacang bulu, tanaman jagung, tanaman obat dan lainnya yang bisa dijadikan sebagai daya tarik bagi para pengunjung. Kawasan ini juga menjadi kawasan ramah lingkungan karena petani tidak pernah menggunakan bahan kimia. Para pengunjung atau wisatawan dapat melakukan beberapa aktivitas di lahan pertanian ini antar lain berkebun dan turun langsung ke tempat lahan terserbut guna mengikutsertakan wisatawan dengan petani untuk memanen hasil tani yang siap panen.Tujuan dari kegiatan pariwisata tersebut dapat berdampak pada peningkatan kesejahteraan masyarakat (Ramly, 2017).

\section{Pengembangan Agrowisata}

Pada hakikatnya kehidupan masyarakat pedesaan masih memiliki sifat gotong royong yang mendalam, yang membuktikan bahwa kehidupan selalu dibarengi dengan berbagai upaya yang dapat menghasilkan upaya yang dapat menghasilkan bekal, bagi kelangsungan hidup. Pertanian adalah salah satu usaha yang sejak lama dan turun temurun, menjadi bagian mata pencaharian masyarakat di pedesaan, usaha pertanian telah membentuk pola hidup masyarakat tidak hanya sekedar mengolah ladang, kebun, persawahan, dan hutan, tetapi apa yang mereka kerjakan dengan tanpa disadari telah membentuk satu daya tarik bagi orang lain yang melihatnya. Misalnya seorang petani yang ,ngawuluku (membajak) sawah dengan menggunakan kerbau sebagai binatang 
penghela bajak, telah memberikan nuansa tradisi budaya masyarakat yang bagi orang lain menjadi daya tarik.

Bentangan sawah ladang yang menghampar luas, telah membentuk nuansa alam. Kehijauan padi pada saat belum menjadi padi matang, nuansa kuning menghampar ibarat permadani yang tak terbatas setiap mata memandang membuat rona alam yang menakjubkan sehingga menjadi daya tarik. Hijaunya sayuran di lereng bukit telah pula membentuk kehijauan pada lereng-lereng bukit dan menambah keindahan. Ranumnya hasil buah-buahan pada kebun-kebun masyarakat, telah mampu memikat wisatawan untuk dapat menikmati kelezatannya. Semua itu adalah potensi produk pertanian yang mampu memadukan hasil pertanian dan menarik orang untuk berkunjung. Inilah makna pertanian yang dapat membantu pengayaan produk wisata dan menjadi bagian penting dalam diversifikasi produk pariwisata. Masyarakat petani dan hasil garapannya merupakan keterpaduan harmonis yang dapat mendorong perkembangan kepariwisataan.

Agrotourism telah berhasil dikembangkan di Switzerland, Selandia Baru, Australia, dan Austria. Sedangkan di USA baru tahap permulaan dan baru dikembangkan di California. Beberapa Keluarga petani sedang merasakan bahwa mereka dapat menambah pendapatan mereka dengan menawarkan pemondokan bermalam, menerima manfaat dari kunjungan wisatawan, (Sudiasa 2005).

Pengembangan agrotourism merupakan kombinasi antara pertanian dan dunia wisata untuk liburan di desa. Konsep ini memberikan daya tarik yang berbeda dnegan jenis wisata lainnya. Seperti yang diungkapkan oleh Damanik dan Weber (2006:13), bahwa daya tarik wisata memiliki empat hal yakni, memiliki keunikan, orisinalitas, otentisitas, dan keragaman. Agrowisata menawarkan sisi keunikan yang dapat dinikmati oleh wisatawan.

Beberapa penelitian telah dilakukan diantaranya oleh Ulfa (2015), Sumantra, (2015) dan Sastrayuda (2010) terkait dengan pengembangan agrotourism. Atraksi dari agrotourism adalah pengalaman bertani dan menikmati produk kebun bersama dengan jasa yang disediakan. Motivasi agrotourism adalah untuk menghasilkan pendapatan tambahan bagi petani. Bagaimanapun, agritourism juga merupakan 
kesempatan untuk mendidik orang banyak/masyarakat tentang pertanian dan ecosystems. Pemain Kunci di dalamagrotourismadalah petani, pengunjung/wisatawan, dan pemerintah atau institusi. Peran mereka bersama dengan interaksi mereka adalah penting untuk menuju sukses dalam pengembangan agrotouris.(Yuesti 2015)

\section{Pariwisata Berbasis Masyarakat}

Pariwisata berbasis masyarakat (Community Based Tourism/CBT) meruapakan pariwisata yang memperhitungkan aspek keberlanjutan lingkungan, sosial, dan budaya (Nurhidayati, 2012; Ernawati, 2010; Hadiwijoyo, 2012; Sznajde,2019). CBT merupakan alat untuk mewujudkan pembangunan pariwisata yang berkelanjutan. Dalam definisi yang disampaikan Suansri, prinsip dasar CBT yang disampaikan Suansri (2003:12) dalam gagasannya yaitu:

a. Mengakui, mendukung dan mengembangkan kepemilikan komunitas dalam industri pariwisata.

b. Mengikutsertakan anggota, komunitas dalam memulai setiap aspek

c. Mengembangkan kebanggaan komunitas

d. Mengembangkan kualitas hidup komunitas

e. Menjamin keberlanjutan lingkungan

f. Mempertahankan keunikan karakter dan budaya di area lokal

g. Membantu berkembangnya pembelajaran tentang pertukaran budaya pada komunitas

h. Menghargai perbedaan budaya dan martabat manusia

i. Mendistribusikan keuntungan secara adil pada anggota komunitas

Berperan dalam menentukan prosentase pendapatan (pendistribusian pendapatan) dalam proyek yang ada di komunitas Sepuluh prinsip dasar tersebut harus menjadi tumpuan, arah dan prinsip dasar dari pembangunan pariwisata agar keberlanjutannya terjamin. 
Secara Konseptual CBT Nurhidayati (2012) diartikan sebagai pendekatan alternatif yang menekankan partisipasi/keterlibatan komunitas serta merupakan alat pemberdayaan ekonomi komunitas. Berikut ini penerapan CBT mensyaratkan terpenuhinya beberapa prinsip yang dapat ditampilkan sebagai berikut. Menurut Suansri (2003), Isnaini (2007) dan Yaman (2004) prinsip Community Based Tourism dilihat dari beberapa segi antara lain :

1) Ekonomi, Terciptanya lapangan pekerjaan sektor pariwisata, Timbulnya pendapatan masyarakat lokal, Timbulnya dana komunitas

2) Sosial, Peningkatan kualitas hidup, Peningkatan kebanggaan komunitas, Pembagian peran yang adil (gender, usia), Mekanisme penguatan organisasi komunitas

3) Budaya, Mendorong masyarakat menghormati budaya lain, Mendorong pertukaran budaya, Budaya pembangunan

4) Politik, Peningkatan partisipasi penduduk lokal, Peningkatan kekuasaan komunitas yang lebih luas, Mekanisme yang menjamin hak masyarakat lokal dalam pengelolaan SDA.

5) Lingkungan, Pengembangan carrying capacity, System pembuangan sampah yang ramah lingkungan, Kepedulian terhadap konservasi.

\section{Analisis Matriks Swot}

Menurut Rangkuti (2017:83-84), alat yang dipakai untuk menyusun faktorfaktor strategis perusahaan adalah matrik SWOT. Matriks ini dapat mengambarkan secara jelas bagaimana peluang dan ancaman eksternal yang dihadapi perusahaan dapat disesuaikan dengan kekuatan dan kelemahan yang dimilikinya.

\section{METODOLOGI}

Metode penelitian mencakup prosedur dan teknik penelitian. Metode penelitian merupakan langkah penting untuk memecahkan masalah-masalah penelitian. Dengan menguasai metode penelitian, bukan hanya dapat memecahkan berbagai masalah 
penelitian, namun juga dapat mengembangkan bidang keilmuan yang digeluti. Selain itu, memperbanyak penemuan-penemuan baru yang bermanfaat bagi masyarakat luas dan dunia pendidikan. Metode penelitian yang digunakan dalam penelitian ini adalah metode penelitian kualitatif. Penelitian kualitatif merupakan penelitian yang humanistik, serta dapat menjelaskan perspektif naturalistik dan perspektif interpretif pengalaman manusia. Peneliti melakukan penelitian ini secara sistematis dan lengkap melalui observasi, wawancara, dan studi dokumentasi. Dengan observasi diharapkan dapat mengetahui secara langsung bagaimana gambaran (1) Agrowisata di Desa Lamajang, (2) Agrowisata Berbasis Masyarakat di Desa Lamajang, (3) Pengembangan Agrowisata di Desa Lamajang.

Berdasarkan konsep diatas, maka penelitian ini menggunakan teknik pengumpulan data adalah observasi, wawancara, dan studi dokumentasi. Bentuk observasi yang digunakan dalam penelitian kualitatif, yaitu "observasi partisipasi, observasi tidak terstruktur, dan observasi terstruktur". Wawancara yang digunakan dalam penelitian kualitatif adalah wawancara secara mendalam adalah proses memperoleh keterangan untuk tujuan penelitian dengan cara tanya jawab sambil bertatap muka antara pewawancara dengan informan, tanpa menggunakan panduan. Adapun butir instrumen wawancara dengan (1) Petani Desa lamajang, (2) Peternak Desa Lamajang, (3) Kelompok Kerja Desa Lamajang, (4) Masyarakat Desa Lamajang.

\section{HASIL DAN PEMBAHASAN}

Desa Lamajang terletak berbatasan di utara dengan Desa Sukamaju, di selatan dengan Desa Pulosari, di barat berbatasan dengan Desa Sukamaju dan Mekarsari, dan di timur berbatasan dengan Desa Cikalong dan Tribaktimulya. Luas wilayah Desa Lamajang adalah 4016,091 hektare dengan ketinggian 900-1.200 Meter dpl. Curah hujan rata-rata 1000-2500 mm/tahun, suhu udara rata-rata 30 derajat hingga 30 derajat. Terdiri dari 5 Dusun, 23 RW dan 92 RT. Penggunaan lahan adalah untuk pertanian 
lahan kering $1001 \mathrm{Ha}$, perkebunan seluas $1.730 \mathrm{Ha}$, permukiman seluas $2006 \mathrm{Ha}$, kolam seluas $4 \mathrm{Ha}$ dan untuk fasilitas desa lainnya seluas $2.145 \mathrm{Ha}$

Dahulu daerah ini adalah pemukiman biasa yang dihuni oleh orang-orang Bandung. Namun semenjak Belanda menginjakan kakinya di Indonesia terutama di Cirebon, banyak orang Cirebon yang berpindah tempat ke Desa Lamajang karena tidak ingin dijajah oleh orang-orang Belanda. Maka dari itu mereka menetap didesa ini. Dikarenakan orang-orang Cirebon rata-rata muslim, lalu disebarkan agama islam di desa lamajang yang sampai sekarang mayoritas penduduknya beragama Islam. Lalu terbentuklah Kampung Cikondang, Desa Lamajang.

Di Desa ini terdapat banyak peninggaan-peninggalan dari leluhurnya seperi Rumah Adat dan Kerajinan Tangannya serta ada pula tempat-tempat pariwisata yang tidak kalah menariknya. Hingga desa ini disebut sebagai Desa Wisata.

\section{Agrowisata Desa Lamajang}

Agrowisata Bidang Lahan Pertanian

a. Tanaman Obat

Desa Lamajang memiliki lahan pertanian di antaranya tanaman obat yang bisa dibilang paling lama ada, karena tanaman obat ini dirintis sejak tahun 1990 dengan luas lahan 1,5 ha dan Bapak (Abah) Engkan sebagai pemiliknya, Bapak Engkan adalah perintis awal pertanian tanaman obat dibantu dengan bantuan kelompok pengembangan pertanian dari Jakarta, Ia mrintis pertanian ini dengan motivasi dari keluarganya untuk mengembangkan lahan pertanian miliknya. Awalnya, lahan pertanian ini belum dipetakan dengan baik, masih pada tanaman campur yang dimanfaatkan khasiatnya dan dikonsumsi oleh pribadi. Tahun 2013 pemerintah khususnya Dinas pertanian dan Dinas perkebunan mulai melihat prospek dari usaha Bapak Engkan ini, dengan memberikan 100.000 tanaman bibit untuk dikelola.

Setelah adanya bantuan dari pemerintah daerah, lahan pertanian ini mulai terkonsep dengan baik, seperti pemetaan sesuai dengan jenis tanamannya. Jenis tanaman yang ada di lahan pertanian ini adalah Tanaman Keras Tulang, Kirinyuh, Daun Mahoni, Sambung Nyawa, Babadotan, Cecenet Leuweung, Honje, Laja, Kunyit, 
Memeniran dan lainnya dengan khasiat dapat menyembuhkan penyakit ringan maupun penyakit berat seperti panas dalam, radang tenggorokan, flu dan batuk, penyakin gula, kanker dan penyakit lainnya.

\section{b. Tanaman Hias}

Desa Lamajang juga memiliki tanaman hias, Tanaman hias ini tumbuh di lahan seluas 0,5 ha. Tanaman hias ini dikelola langsung oleh pemiliknya yang juga menjadi masyarakat Desa Lamajang, Jenis tanaman hias yang ada adalah Tanaman Kemuning, Pucuk Merah, Bunga Mawar Merah, Dan lainnya, Tanaman Hias ini dikelola dengan baik dan dijadikan sebagai tempat kunjungan para wisatawan yang datang untuk melihatnya bahkan membelinya sebagai buah tangan. Namun demikian tanaman hias belum terpetakan dengan baik.

\section{c. Kebun Sayuran}

Di Desa Lamajang juga memiliki lahan pertanian Sayuran, seluas 2 ha, Lahan pertanian sayuran ini sangat indah sebagai sebuah daya tarik wisata. Jenis tanamannya terdiiri dari: Jagung, Kubis, Selada, Kacang-kacangan, Bawang, Tomat, Cabai dan lainnya, Hasil pertanian sayuran ini biasanya di konsumsi oleh pribadi atau pemiliknya dan ada juga sebagian kecil yang dijual kepada pengempul untuk mendapatkan keuntungan lebih bagi pemiliknya. Namun demikian akses jalan menuju pertanian sayuran ini masih terlalu kecil dilalui oleh wisatawan.

\section{d. Kebun Buah-buahan}

Selain itu di Desa Lamjang juga memiliki lahan Pertanian Buah-buahan dengan lahan seluas 1 ha, Jenis Buah yang di tanam di lahan pertanian ini seperti: Jambu biji, Jambu Air, Nangka, Kakao, dan lainnya. Tanaman buah di lahan pertanian di desa ini bisa dibilang masih kurang berkembang dikarenakan masyarakat yang bertanam di buah - buahan masih jarang, sebagian kecil dikelola oleh pemiliknya langsung sama hal nya seperti sayuran hasil pertanian buah-buahan ini biasanya dikonsumsi oleh pribadi dan sebagian kecil dijual ke pengepul dan diolah untuk dijadikan produk 
makanan. Dari segi wisatawan, kebun buah ini hanya aspek pendukung dalam penjualan buah - buahan mengingat lokasi kebun tidak terkonsentrasi dalam sebuah taman.

\section{e. Kebun Kopi}

Lahan pertanian kopi ini bisa dibilang sangat baru di Desa Lamjang, karena pertanian kopi baru muncul dalam Pariwisata saat-saat ini. Dengan luas lahan 0,2 ha Kebun kopi ini bisa Menghasil kan puluhan kilo buah kopi yang nantinya hasil dari panen kopi ini dikumpulkan dan dijual oleh pemiliknya kepada pengepul. Dari segi Agrowisata lebih dilihat pada aspek pendidikan (Eduwisata).

Hasil penelitian terhadap Agrowisata bidang pertanian menujukkan bahwa, Agro yang ada sudah memenuhi unsur - unsur Agrowisata, di mana tanaman obat sudah tertata dengan baik dan sudah mendapat perhatian dari pemerintah daerah. Untuk tanaman hias sudah memiliki keragaman yang memenuhi unsur Agrowisata namun demikian belum dipetakan secara terkonsep. Untuk kebun sayuran memiliki keragaman sayur namun akses menuju area tanaman masih sempit, untuk kebun buah ditanam secara individu tidak terpetakan secara khusus. Untuk kebun kopi memang lebih pada aspek eduwisata. Jika dilihat dari aspek berbasis masyarakat sudah terpenuhi, karena sepenuhnya lahan pertanian ini dikelola langsung oleh masyarakat di sekitarnya,

Agrowisata Bidang Peternakan

a. Peternakan Ayam

Di Desa Lamajang selain memiliki pertanian juga memiliki peternakan, salah satunya adalah peternakan ayam. Ternak ayam di Desa ini cukup banyak dikarenakan masyarakat sebagian besar memiliki peliharaan ayam dan dijadikan bahan olahan untuk dikonsumsi. Dalam bidang Agrowisata di Desa ini cukup terbilang baru karena masyarakat melihat bahwa karakteristik wisatawan jaman sekarang yang keingintahuaannya sangat tinggi dari mulai memberi makan ayam, mengurus ayam serta mengolah ayam hingga menjadi pangan untuk dikonsumsi. Dengan hal tersebutlah masyarakat Desa Lamjang ini membuatkan lahan peternakan ayam yang 
khusus bisa di datangani oleh wisatan yang berkunjung dan mengetahui tata cara mengurus ayam dan pengolahannya

b. Peternakan Domba

Di desa ini juga memiliki peternakan Domba, Peternakan Domba ini sebenarnya dikhususkan untuk wisatawan yang memang ingin melihat atau meneliti tentang hewan dan masih tergolong kurang untuk jumlah domba yang ada. Peternakan Domba ini dimiliki oleh salah satu warga di Desa Lamajang Namun demikian hal ini masih tahap proses pengembangan untuk dijadikan Agrowisata dan dikunjungi oleh wisatawan umum

\section{c. Peternakan Burung Merpati}

Peternakan Burung Merpati di Desa Lamajang ini sudah cukup baik dan dikelola oleh salah satu masyarakat Desa Lamajang juga, Pengelola Burung Merpati mengawali Ternak nya ini dimulai dari kesukaannya terhadap burung Merapati, Dengan Luas lahan ternak yang cukup Pengelola memiliki banyak jenis burung Merpati dan dapat dikunungi oleh wisatawan jika ingin melihatnya dan bermain bersama burung Merapti ini. Namun demikian untuk tempat masih terbatas jika wisatawan yang berdatangan dalam jumlah yang cukup banyak.

\section{d. Budidaya Ikan}

Di Desa Lamajang juga memiliki budidaya ikan yang biasanya dikelola oleh masyarakat dan dikonsumsi oleh pribadi dan sebagian kecil dijual dan dijadikan kolam pancing untuk wisatawan yang ingin memancing. Jenis ikan yang ada di Desa Lamajang ini sama halnya seperti jenis ikan pada umumnya seperti Ikan Mas, Ikan lele, Ikan Mujair dan lainnya. Namun untuk bidang Agrowisata nya Budidaya ikan ini belum terkonsep dengan baik dari segi lahan dan pemetaannya.

Hasil penelitian Agrowisata dalam bidang peternakan dilihat sudah memiliki unsur - unsur Agrowisata yang dapat dikunjungi oleh wisatawan, dimana peternakan ayam yang sudah memiliki jumlah yang cukup banyak namun belum terkonsep dengan baik, Untuk peternakan domba menjadi aspek pendukung dalam pengembangan 
Agrowisata namun masih pada tahap proses pengembangan, Untuk peternakan burung merpati sudah terdapat banyak jenis dan dapat dijadikan daya tarik wisata namun lahan peternakan yang masih sempit untuk dikunjungi oleh wisatawan, Untuk Budidaya ikan menjadi salah satu kegiatan wisatawan saat berkunjung namun demikian hal tersebut belum terkonsep dengan baik.

\section{Kegiatan Pertanian}

Kegiatan pertanian (Agriclutural activity) adalah salah satu pemanfaatan sumber daya hayati yang dilakukan manusia untuk menghasilkan bahan pangan, bahan baku industri atau sumber energi. Di Desa Lamajang sendiri kebiasaan petani bertani nya cukup baik karena dilihat dari proses pengelolaannya yang baik dan berkelanjutan dari musim ke musimnya, para petani di Desa Lamajang ini juga sudah mengenak seperti jenis pupuk dan vitamin tanaman untuk menyuburkan tanah dan tanaman agar sehat dan hasil panennya memuaskan, tetapi dengan begitu masih saja kurang pemahaman tentang penjualan hasil pangan ke luar Desa Lamajang ini.

Mereka beranggapan bahwa hasil pertanian yang dihasilkan kebanyakan di konsumsi untuk pribadi hanya sedikit yang dijual kepada pengepul, Kurangnya pelatihan yang merata terhadap seluruh petani yang ada di Desa Lamajang, dan kurangnnya bantuan pemerintah terhadap pengembangan pertanian di Desa Lamajang ini.

\section{Agrowisata Berbasis Masyarakat Di Desa Lamajang}

\section{Aspek Ekonomi}

Aspek ekonomi merupakan dampak yang dapat dirasakan secara nyata oleh masyarakat, Pengembangan Agrowisata di Desa Lamajang Kabupaten Bandung di paparkan sebagi berikut:

a. Terbukanya Peluang Usaha di Bidang Pariwisata

Pariwisata yang berkelanjutan mampu membuka peluang usaha bagi masyarakat dalam bidang pariwisata, hal ini belum terjadi dengan baik di Desa Lamajang Kabupaten Bandung. Peluang usaha yang dihasilkan masih kecil dan dengan cara masyarakat yang 
terus mengembangkan sebagai sumber mata pencaharian seperti menjadi petani, peternak, dan beberapa menjadi pengepul dari hasil tani. Peluang usaha yang terdapat di Desa Lamajang ini diharapkan nantinya mampu menarik minat masyarakat untuk berpenghasilan yang lebih tinggi.

b. Peningkatan Pemasukan Pelaku Usaha

Dengan adanya Agrowisata yang menunjang telah berdampak Ekonomi yang dapat dirasakan langsung oleh masyarakat di Desa Lamajang Dengan adanya peluang usaha dan pengembangan agrowisata ini masyakat bisa merasakan dengan mendapatkan penghasilan lebih dari lahan pertaniannya yang dijasikan agrowsiata dan dikunjungi oleh wisatawan.

\section{Aspek Sosial}

Desa Lamajang merupakan bagian dari wilayah Kabupaten Bandung yang dimana untuk masyarakatnnya sendiri ini didominasi oleh suku sunda, hal ini menunjukan pada pengembangan agrowisata berbasis masyarakat. Pembahasan yang dilakukan peneliti sebagai berikut,

\section{a. Peningkatan Kualitas Hidup Masyarakat}

Manfaat Ekonomi dan sosial dari pengembangan agrowisata berbasis masyarakat di Desa Lamajang ini akan meningktkan kualitas hidup mereka yang tadinya tidak tahu menjadi tahu mengenai perkembangan pariwisata, yang tadinya masyarakat hanya mendapatkan pemasukan atau penghasilan dari hasil tani yang dijual saja tapi dengan adanya perkembangan pariwisata yang bisa menambah pemasukan yang akan meningkatkan kualitas hidup mereka.

\section{b. Meningkatkan Softskill Masyarakat}

Dengan cara mengembangkan agrowisata berbasis masyarakat di Desa Lamajang ini yang sangat berperan penting yaitu masyarakatnya sendiri. Masyarakat dituntut harus bisa menjadi Pengarah jalannya kegiatan usaha pariwisata di Desa Lamajang ini, Dengan cara bisa menyambut wisatawan dengan ramah, menujunkan arah tempat yang dituju dan sebagainya. Dengan hal itu Masyarakat sudah dapat merasakan perilaku yang berubah dalam dirinya menjadi lebih merespon dengan baik pada saat wisatawan berkunjung. 
c. Menumbuhkan rasa percaya diri masyarakat

Dalam pengembangan pariwisata juga bisa menjadikan masyarakat lebih percaya diri dalam dirinya, dilihat dari diri masyarakat yang sudah mengetahui bahwa lingkungannya berpotensi untuk dijadikan tempat wisata dan mereka juga memiliki keahlian yang apa adanya tapi sangat menarik wisatawan, contohnya bertani yang biasa masyarakat lakukan dari menandur hingga panen hal ini diarasa oleh masyarakat biasa saja tapi sebagai wisatawan merasa tertarik untuk melakukan hal tersebut.

d. Masyarakat tergabung dalam Komunitas

Dengan adanya usaha pariwisata, hal ini mengajak masyarakat untuk membuat komunitas khusus pariwisata dengan tujuan untuk mengembangan pariwisata di Desa Lamajang ini dengan baik, Masyarakat lebih aktif dalam berorganisasi dan membuat kelompok kerja yang dikhususkan untutk pengembangan pariwisata di Desa Lamajang ini.

\section{Aspek Lingkungan}

Pengembangan Agrowisata Berbasis Masyarakat di Desa Lamajang ini memberikan harapan bagi masyarakatnnya yang dapat dikelola secara berkelanjutan. Keberlanjutan Desa ini tidak terlepas dari mkondisi lingkungannya, baik kondisi alam, lahan pertanian, dan fasilitas pendukung. Peneliti membahas hal tersebut dalam aspek lingkungan sebagai berikut,

\section{a. Meningkatkan Kelestarian Lingkungan Hidup}

Perkembangan pariwisata dan lingkungan hidup memiliki hubungan yang sangat erat terlebih agrowisata yang memanfaatkan lahan lingkungan untuk dijadikannya sebagai potensi pariwisata. Desa Lamajang ini telah menyusun lingkungan dengan sebaikbaiknya dengan memetakan daerah atau lahan yang siap dijadikan untuk pengembangan Agrowisata dan tidak mengganggu aktivitas masyarakat lain untuk bekerja, juga Masyarakat telah menyusun dan menata lingkungan di Desa Lamajang ini agar tidak merubah lingkungan bahkan merusaknya.

b. Sarana dan Prasarana yang Optimal 
Aspek lingkungan yang berpengaruh dalam pengembangan Agrowisata di Desa Lamajang ini bukan hanya kelestariannya, tetapi aspek sarana dan prasarana juga berperan penting dalam mengembangkan agrowisata di Desa Lamajang ini. Masyarakat Desa Lamajang ini hanya memiliki sebagian sarana prasarana yang mendukung hal kecil untuk pengembangan Agrowisata ini seperti toilet, titik kumpul dan belum mampu memiliki sarana yang baik untuk lebih menunjang pengembangan Agrowisata yang baik

\section{Aspek Budaya}

Desa Lamajang memiliki masyarakat yang lebih memilih menjadi seorang petani dalam bermatapencahariannya, karena hal itu kegiatan bertani menjadi budaya mereka dalam meningkatkan kualitas hidupnya dan mendorong generasi muda untuk meneruskannya. Dengan begitu peneliti menjabarkan sebagai berikut:

Mempertahankan keunikan karakter dan budaya Desa Lamajang, masyarakat Desa Lamajang memiliki kebiasaan bertani dalam kehidupan sehari - harinya, hal ini menunjukan bahwa masyarakat sudah memiliki kemampuan bertani yang mempuni dalam memproses hasil tani dengan baik

\section{Aspek Politik}

Pemerintah dan masyarakat memiliki peran masing-masing dalam pengembangan Agrowisata di Desa Lamajang ini, tetapi kedua pihak tersebut tidak dapat dipisahkan karena memiliki keterkaitan dalam pengembangan Agrowisata ini. Peneliti menjabarkan salah satu aspek politik dalam pengembangan Agrowisata sebagai berikut,

Keterlibatan Pemerintah Dalam Mendukung Pengembangan Agrowisata, Desa Lamjang ini tidak memungkiri bahwa ada bantuan pemerintah didalamnya untuk pengembangan Agrowisata di Desa Lamajang ini, Pemerintah memberikan bibit tanaman kepada masyarakat Desa Lamajang ini guna untuk mendukung pengembangan Agrowisata di Desa ini, Masyarakat merespon dengan baik pemberian 
bibit tanaman yang diberikan oleh pemerintah dan dikelola dengan baik hingga sekarang.

\section{Pengembangan Agrowisata Di Desa Lamajang}

Strategi Pengembangan Menggunakan Matriks SWOT

Matriks SWOT memberikan gambaran dengan jelas tentang faktor-faktor yang menjadi kekuatan dan kelemahan serta peluang dan ancaman yang dimiliki agrowisata Desa Lamajang.Matriks SWOT berisi strategi kombinasi S-O (StrengthOpportunities), S-T (Strength-Threats), W-O (Weakness-Opportunities), dan W-T (Weakness-Threats).

Setelah mengetahui posisi agrowisata Desa Lamajang dan didapatkan inti strategi berdasarkan kekuatan, kelemahan, peluang dan ancaman, maka dapat diformulasikan alternatif strategi. Formulasi strategi ini dilakukan dengan menggunakan matriks SWOT. Matriks SWOT agrowisata Desa Lamajang dapat dilihat pada Tabel

\section{Tabel}

\section{Analisis Matriks SWOT}

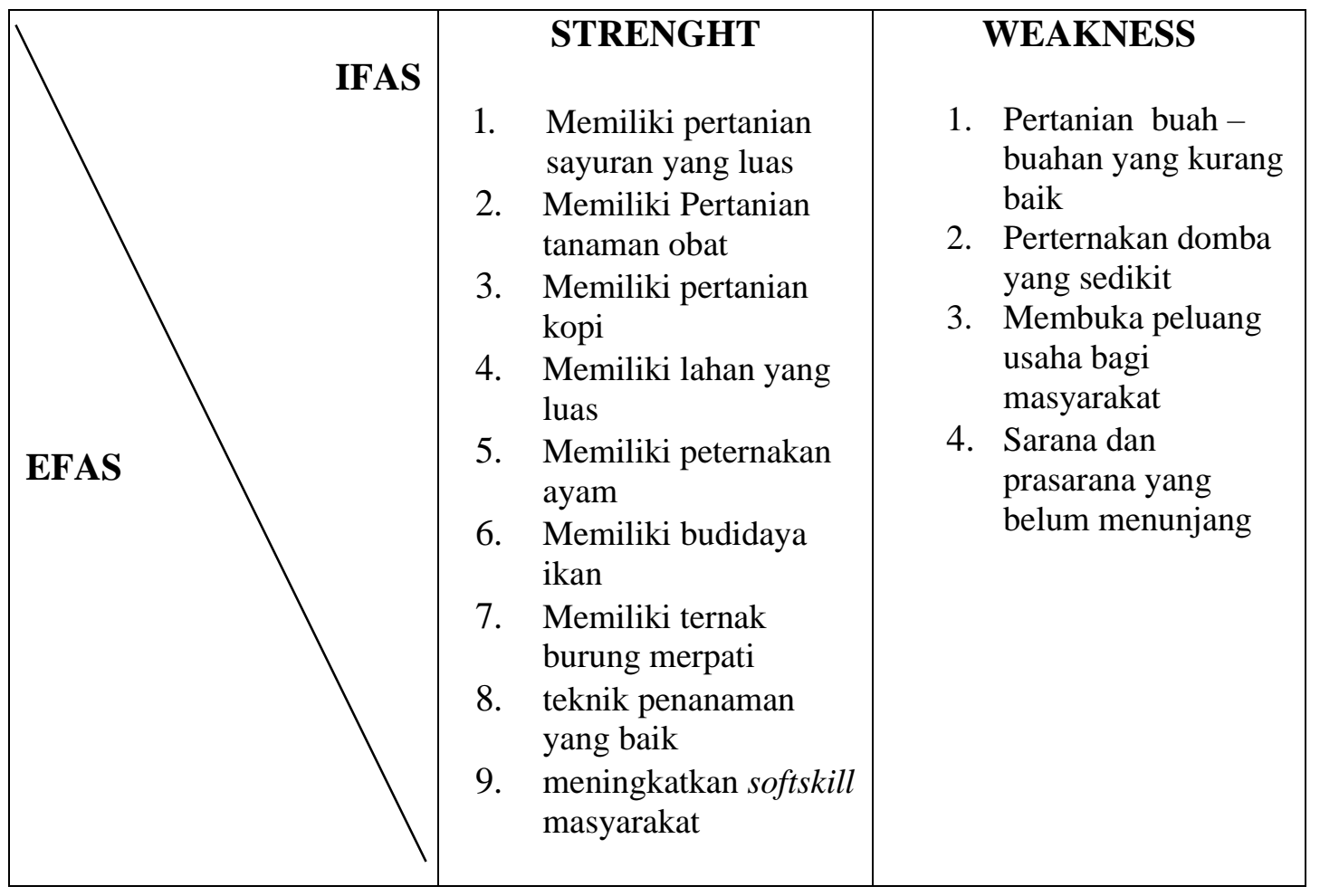




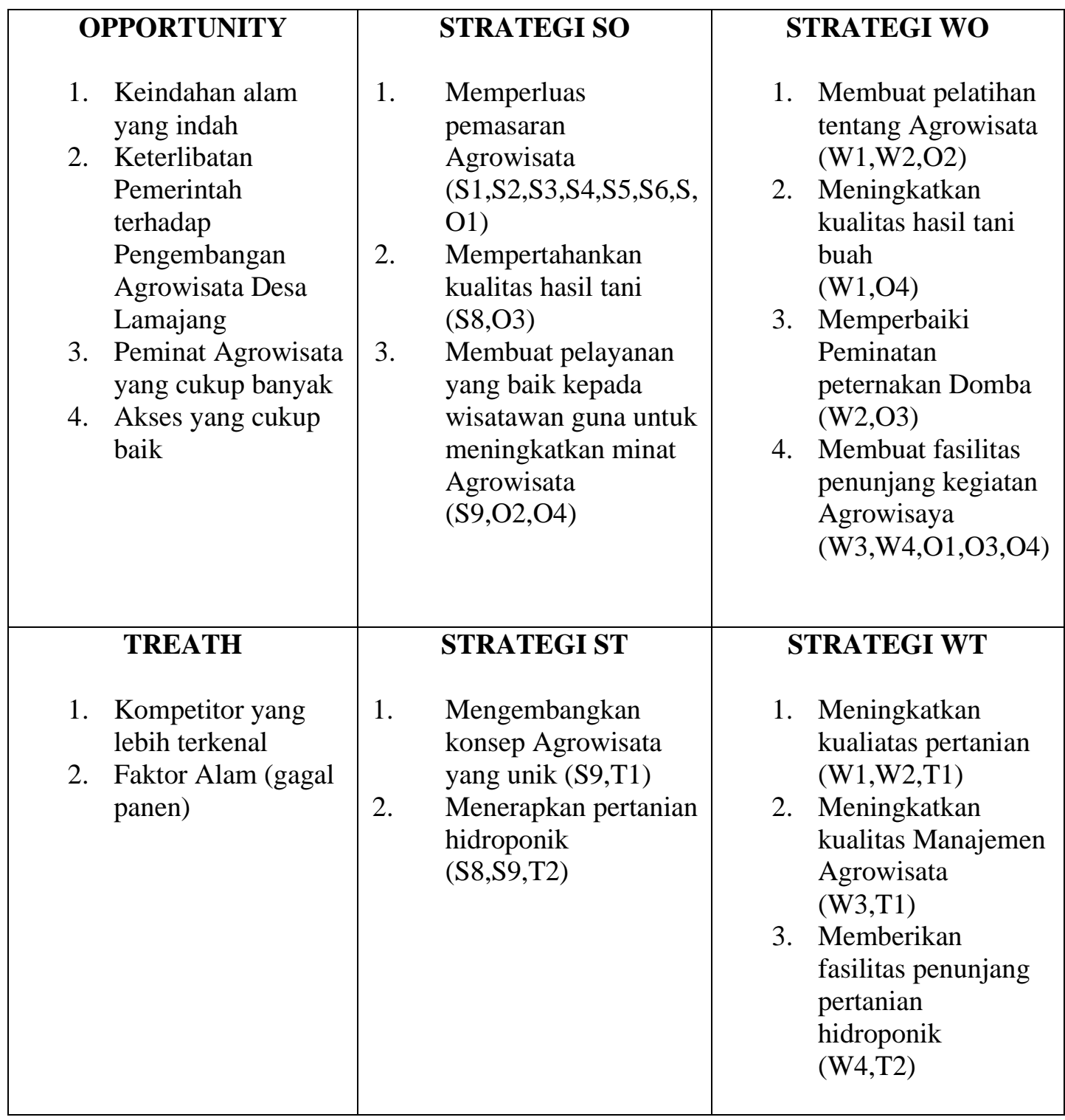

Sumber: Data yang diolah

\section{SIMPULAN}

Berdasarkan hasil penelitian dan pembahassan maka dengan ini peneliti menyimpulkannya sebagai berikut:

\section{Agrowisata Di Desa Lamajang}

Desa Lamajang memiliki Lahan pertanian yang cukup luas, di antaranya pertanian sayuran, buah-buahan, tanaman hias, tanaman kopi. Pertanian ini dikelola dan dikembangkan oleh masyarakat setempat yang juga sebagai petani pada bidang 
taninya, selain pertanian di Desa Lamajang ini juga memiliki peternakan yang cukup baik diantaranya peternakan ayam, peternakan domba, budidaya ikan, dan burung merpati. Namun demikian belum adanya pemetaan yang cukup baik dan belum adanya fasilitas yang menunjang Pengembangan Agrowisata di Desa Lamajang

\section{Agrowisata Berbasis Masyarakat di Desa Lamajang}

Lahan pertanian, peternakan di Desa Lamajang ini dikelola langsung oleh masyarakat Desa Lamajang, hal ini menunjukan bahwa Agrowisata di Desa Lamajang ini yang berbasis Masyarakat dilihat dari beberapa asspek diantaranya Aspek sosial, ekonomi, budaya, lingkungan dan politik yang bisa menjadikan peluang usaha masyarakat dalam bidang pariwisata. Namun demikian masyarakat masih kurang paham tentang konsep Agrowisata yang baik.

\section{Pengembangan Agrowisata Berbasis di Desa Lamajang}

Posisi dan kondisi Agrowisata di Desa Lamajang di Internal 2,88 dan Eksternal 2,47, Dengan titik kuadran menggunakan GE Matriks Selectivity yaitu pada posisi middle yang artinya Desa Lamajang memiliki keunggulan yang bisa dijadikan peluang daya tarik wisata pada bidang Agrowisata dan dapat meminimalisir kelemahan dengan cara pengembangan Agrowisata guna mampu bersaing dengan kompetitor juga mengendalikan ancamam yang ada

Dan selanjutnya pengelola Agrowisata di Desa Lamajang perlu menyusun rencana strategis jangka pendek, jangka menengah, dan jangka panjang.

\begin{tabular}{|l|l|c|c|c|}
\hline \multirow{2}{*}{ No. } & \multicolumn{1}{|c|}{ Uraian Program } & \multicolumn{3}{c|}{ Rencana Strategis } \\
\hline & & Jk. Pendek & Jk. Menengah & Jk. Panjang \\
\hline 1. & Memperluas Pemasaran Agrowisata & $\checkmark$ & & \\
\hline 2. & Mempertahankan kualitas hasil tani & $\checkmark$ & & \\
\hline 3. & $\begin{array}{l}\text { Membuat pelayanan yang baik kepada } \\
\text { wisatawan guna untuk meningkatkan } \\
\text { minat Agrowisata }\end{array}$ & & $\checkmark$ & \\
\hline 4. & $\begin{array}{l}\text { Membuat pelatihan tentang } \\
\text { Agrowisata }\end{array}$ & & $\checkmark$ & \\
\hline 5. & Meningkatkan kualitas hasil tani buah & & & $\checkmark$ \\
\hline
\end{tabular}




\begin{tabular}{|c|c|c|c|c|}
\hline 6. & $\begin{array}{l}\text { Memperbaiki Peminatan peternakan } \\
\text { Domba }\end{array}$ & & & $\checkmark$ \\
\hline 7. & $\begin{array}{l}\text { Membuat fasilitas penunjang kegiatan } \\
\text { Agrowisaya }\end{array}$ & & & $\checkmark$ \\
\hline 8. & $\begin{array}{l}\text { Mengembangkan konsep Agrowisata } \\
\text { yang unik }\end{array}$ & & $\checkmark$ & \\
\hline 9. & Menerapkan pertanian hidroponik & & $\checkmark$ & \\
\hline 10. & Meningkatkan kualiatas pertanian & $\checkmark$ & & \\
\hline 11. & $\begin{array}{l}\text { Meningkatkan kualitas Manajemen } \\
\text { Agrowisata }\end{array}$ & $\checkmark$ & & \\
\hline 12. & $\begin{array}{l}\text { Memberikan fasilitas penunjang } \\
\text { pertanian hidroponik }\end{array}$ & & $\checkmark$ & \\
\hline
\end{tabular}

\section{DAFTAR RUJUKAN}

Damanik, Janianton \& weber F. Helmut 2008. Perencanaan Ekowisata. Penerbit Andi Yogyakarta

Ernawati, Ni Made. (2010). Tingkat kesiapan desa sebagai tempat wisata berbasis masyarakat. Bali : Politeknik Negeri Bali. Jurnal Analisis Pariwisata Vol.10.

Hadiwijoyo, Surya Sakti. (2012). Perencanaan Pariwisata Perdesaan Berbasis Masyarakat (Sebuah Pendekata Konsep). Yogyakarta : Graha Ilmu

Isnaini. (2007). Model Pengembangan Pariwisata Berbasis Masyarakat di Kota Yogyakarta. Jurnal Penelitian Bappeda Kota Yogyakarta Edisi No.2, Desember 2007

Ramly, (2007) Dasar - Dasar Manajemen Kepariwisataan Alam, Yogyakarta: Liberty Offset.

Ramly, N. 2007. Pariwisata Berwawasan Lingkungan. Grafindo KhazanahIlmu. Jakarta.

Rangkuti, F. 2017. Teknik Membedah Kasus Bisnis Analisis SWOT. Gramedia Pustaka Utama.

Suansri, Potjana. 2003. Community Based Tourism Handbook. Thailand: REST Project.

Sumantra IK., Yuesti A, \& Sudiana AAK. (2015). Pengembangan agrowisata salak berbasis masyarakat Di Desa Sibetan. Vol. 4 No.2

Suwantoro. G. (2004). Dasar-dasar Pariwisata. Penerbit Andi Yogyakarta 
Sznajder, M., L., Pzezborska, and F. Scrimgeour. (2009). Agritourism. UK: AMA DataSet Ltd.

Ulfa AN., Marwanti S, \& Utami BW. (2015). Persepsi Dan Tingkat Pasrtisipasi Petani terhadap Pengembangaan Desa berbasis Agrowisata (Studi Kasus Di Desa Berjo Kecamatan Ngargoyoso di kabupaten karanganyar). Vol. 3 No.3, Hal. 232 $-238$

Yaman A. Dan Mohd, Abdullah. (2004). Community Based Ecoturism: New Proposition for Sustainable Development and Environment Conservation in Malaysia. Journal Of Applied Sciences.

Yuesti, A. (2015). Pengembangan model agrowisata salak berbasis masyarakat di Desa Sibetan.

Sastrayuda, Gumelar S, (2010). Konsep Pengembangan Kawasan Agrowisata. Hand Out Mata Kuliah Concept Resort And Leisure, Strategi Pengembangan Dan Pengelolaan Resort And Leisure. http://file.upi.edu.gumelar_s.go.id [25 Agustus 2019] 